\title{
JOHN A. KASSON, AN AUTOBIOGRAPHY ${ }^{1}$
}

John Adam Kasson was born in the country town of Charlotte, Vermont, January 11, 1822.

His parents were John Steele Kasson and Nancy Blackman, who were fairly educated country people, intelligent and irreproachable in character, who migrated from Connecticut to Vermont in 1816. Both were devoted to giving the best education obtainable to their children, of whom the youngest was the above named. Their father died in 1828, the mother in 1860 .

The blood was Scotch-Irish mingled with English. Adam Kasson with Jane Hall, his wife, and nine children sailed from Ulster, Ireland, in 1722 to Boston, Massachusetts, and taking a body of land lying partly in Rhode Island and partly in Connecticut settled upon it. Thence their descendants have scattered to Massachusetts, Vermont, New York, Pennsylvania, Illinois, Wiseonsin, Minnesota, Iowa, Louisiana and California.

James, sixth son of the first emigrant, Adam, built a homestead at Bethlehem, near Litchfield, Connecticut, in 1760, which remained in the family 130 years. To him and his wife, Esther Dunean, was born in 1763, Adam his tenth child. He married Homour Steele, descendant of that John Steele who was one of the proprietors of Cambridge, Massachusetts, and after being a member alternately of both upper and lower house of the Colonial Legislature and its secretary, became afterwards a leader and founder of the town of Hartford, Connecticut and its registrar for many years. For him this Adam's son, John Steele Kasson was named; and this latter was the father of John A. Kasson, his youngest child.

Of the ancestral family Robert Kasson served in the French and Revolutionary Wars, and Colonel Archibald Kasson

\footnotetext{
TThis sketch was written by Mr. Kasson a few years before his death, for an eastern publishing company, and the document as he wrote it is on file in the Historical Department. The great career of this fllustrious statesman and international diplomat justifies the laudatory statements he makes about himself.-Editor.
} 


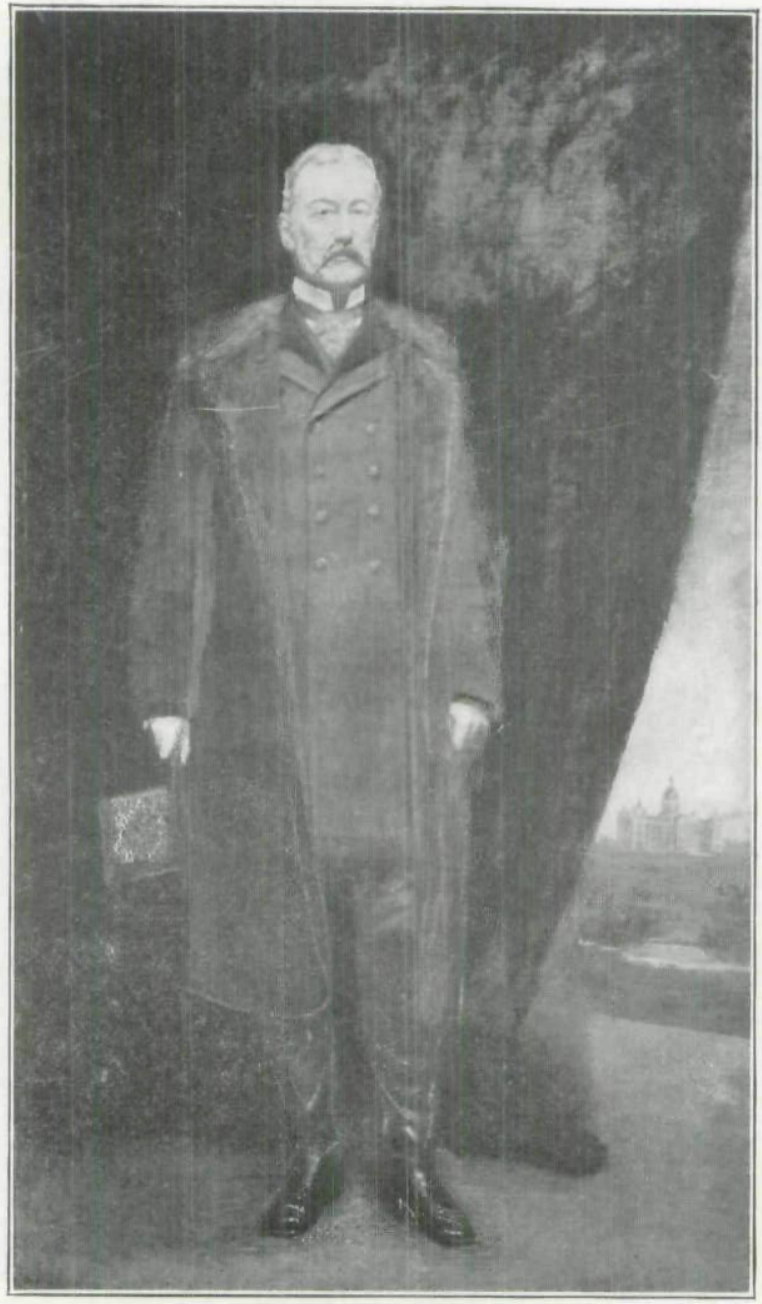

JOHN A. KASSON

The original painting from which this cut is made hangs in the portrait gallery of the Historical Department of Iowa 
served throughout the Revolutionary War, and at its elose was honored with a brigadier general's commission. Of the Blackmans one is known to have been a lieutenant and member of an expeditionary force to Ticonderoga, and his notebook thereof remains in the family.

John Adam Kasson was educated at the University of Vermont, in Burlington, and graduated in 1842, ranking first in Greek, and second in average of all studies.

His earliest experiences were on a farm near Lake Champlain, and at the common school of the town. Having been orphaned by the death of his father at the age of six years, the family afterwards settled in Burlington for his education, and that of his eldest brother, Charles de Forest Kasson, in the study of the law. The younger brother developed a taste for reading and study, was fond of horses and dogs, and was ambitious and diligent in his studies at school and the university. After graduation, restless and eager to see the world, he took a position as tutor in a Virginia family for a few months-returned to Burlington and began the study of the law. Again restless under his limitations and having a few extra dollars in his pocket, he left without adieus to the family for Boston, tried to embark for a sailing voyage on an old schooner fit for shipwreck, failed, turned inland to Worcester, Massachusetts, where he arrived with his funds exhausted, and entered the law office of Emory Washburn, afterward judge and governor of Massachusetts. He was admitted to the bar by Judge Washburn in 1844 . After consulting the distinguished Rufus Choate at Boston, he went to pursue his profession at New Bedford. There he formed a partnership with Thomas Dawes Eliot, and had much practice from that whaling port in the courts of admiralty at Boston. At this time he published an article in the "Law Reporter" advocating a reform in the eumbrous common law system by simplification of pleadings, partial disuse of juries, and diminution of legal expenses. He also took part in the anti-slavery movement of 1848 , was sent as a delegate to the Free Soil Convention at Buffalo, and was on his return nominated for eongress on that issue from the 
New Bedford District, a nomination which at that early age he had the good sense to decline.

Still feeling the pressure on him of the settled institutions and the hereditary systems of that old society, his desires turned to the new and open West, where west of the Allegheny Mountains all traveling was then done by boat on rivers and lakes and by stage coach or wagon or horseback across country. Having by this time some surplus earnings in money, he removed in 1850 to St. Louis, Missouri, where he arranged for law practice with J. B. Crockett, afterwards a supreme judge in California, to whose business he succeeded. For a short time he associated with him Hon. B. Gratz Brown, afterward United States senator from Missouri and a candidate for vice president on the Greeley ticket. He was very successful in his practice at that bar, which was then distinguished by such men as Henry S. Geyer, afterward a United States senator, and Edward Bates, afterward United States attorney general under Lineoln.

He continued in his profession there until 1856, when he found his health deteriorating under the influence of that climate, and the controlling pro-slavery elements of Missouri were distasteful to him. After a year of comparative idleness and a tour in Europe, he finally in 1857 established himself at Des Moines, Iowa, which had just then been declared the new and permanent eapital of that young state. It was then a large struggling village, but full of hope and ambition as the coming capital city. He soon had a large docket as an attorney, the docket much fuller than his purse. Hard-working farmers, but no money. Panic of 1857 impoverished everybody. There was no river navigation nor railroad to the eapital. Road and bridges bad, and wagon transportation slow and eostly. The wagon which earried him for two days and nights to Des Moines broke down before reaching the city, leaving him to walk the remaining distance through the mud to his future home. Everything discouraging. But he stuck to his purpose of sharing the fate and fortune of this frontier and western people. Years of weary waiting, in which he formed his close attachment to his fellow-frontiersmen, who afterward stood so constantly by him in many 
political contests. In his political campaigns he travelled in open wagons, he ate in their kitchens, slept when necessary on the floors of their cabins or in the hay loft, and shared their deprivations. Without wrangling over unpaid fees, he sometimes accepted in place of money a load of vegetables which a farmer would bring him.

In 1858-59 he was made chairman of the Iowa State Republican Committee, and organized for the first time systematically the Republican party of that state. He was also appointed by Governor Lowe chairman of a commission to examine and report upon the condition of the executive offices of the state, which had just been removed to the new capitol, and made report thereon recommending various improvements of administration. He was also made a state director in the newly organized State Bank of Iowa. In 1860 he was sent as delegate from the state at large to the Republican National Convention at Chicago which nominated Lincoln. He was chosen to represent that state in committee on resolutions, and on the sub-committee which framed the platform. After an all-night session of this committee of five, of which Horace Greeley was one, Kasson was left to reduce the platform to its final shape and style, while Greeley, as the morning sun was rising, left the room to telegraph the New York Tribune that the platform was complete, and that eredit for it was chiefly due to John A. Kasson of Iowa, as appears by the Tribune of that issue. From that lime throughout the eampaign he was on the stump in the West advocating the election of Abraham Lincoln, and supporting that clause of the platform which he himself had penned, that "the normal condition of all the territories of the United States was that of freedom."

Joyous over the wonderful vietory of his party in 1860 , and made anxious by the threatening organization of rebellion, he travelel to Washington to witness the inauguration of the new president in March, 1861. Intensity of feeling was there divided between the rebellious movement in the South and the organization of the new eabinet. Montgomery Blair, whom he had known as a judge in St. Louis had been selected for postmaster general. By desire of Senator Grimes 
of Iuwa Mr. Kasson was most unexpectedly offered the place of first assistant postmaster general and accepted it. His nomination was the second sent to the Senate by President Lineoln for confirmation, the first being that of Mr. Lincoln's personal friend, Mr. Judd of Illinois for minister to Prussia.

In this way Mr. Kasson was introduced into that branch of the national service where as it later appeared he was to render some historical service in national and international postal relations. At first he was overwhelmed with the work of discharging and appointing postmasters, sometimes reaching six hundred changes in one day, both on aceount of polities and for disloyalty. In those days civil service reform had not been introduced. Mail communications with the Secession States were broken up. As our armies advanced southward Kasson prepared an army postal system which was approved by the military authorities and used during the war. As soon as this pressure of official duties was relieved, he turned his attention to the condition of the postal laws. They were seattered through many statutes. He prepared a postal code, eliminating obsolete provisions. $\mathrm{He}$ found different rates prevailing to different parts of the country. He proposed legislation to make them uniform, and this was adopted. In respect to foreign countries he found as many differing rates as there were nations, and a complicated system of international accounts, under which this country was brought largely in debt for balances each year to the foreign governments. This balance was payable in gold, the premium on which cost the United States Government many added thousands for exchange. To remedy these inconveniences Kasson proposed to Mr. Blair to invite an international postal conference to make lower and more uniform rates, to simplify postal treaties, and for the abolition of international accounts. The detailed plan being approved by the postmaster general, invitations were sent through the secretary of state, which were accepted by fifteen nations who were represented in the conference held at Paris in 1863. Kasson was the commissioner representing the United States, and his propositions were the basis and the beginning of that great international postal reform, which 
has now become the admiration as well as the convenience of the civilized world. At its coneluding session the Conference ordered Mr. Kasson's closing address to be inserted in the Proces Verbal, together with an acknowledgment of the obligation of the conference to "the enlightened and at the same time conciliatory spirit" which he had constantly presented in their deliberations. (Proces Verbal of June 8, 1863.) Kasson remained long enough in Europe to visit several of the governments and make preliminary conventions with them on the new basis.

He returned toward the close of that year to take his seat in the Thirty-eighth Congress, to which he had in the meantime been elected, representing twenty-three counties of southwestern Iowa. He was re-elected in 1864 to the Thirtyninth Congress. During this time he made annual tours of his large district, speaking in every county, ardently advocating the support of Mr. Lincoln, and arousing and maintaining the popular determination to make all sacrifices for the maintenance of the Union and for the extinction of slavery. In the Thiriy-eighth Congress he was appointed by Speaker Colfax on the leading committee, Ways and Means, which also at that time included Appropriations. In the Thirty-ninth Congress he was appointed on the Committee of Appropriations, and chairman of the Committee on Coinage, Weights and Measures. While on this latter committee he initiated and earried through Congress the first bill ever passed for the introduction of the decimal system of weights and measures into the United States, adopting the metric system of France. He also reported a bill which was passed, for abolishing the smaller denominations of paper money. On his proposition a measure was also adopted for introducing consular clerks into that service, irremovable except for cause-the first step in the congressional reform of civil service. Became prominent among congressional debaters in various departments of legislation, and secured the introduction of a clause into the Bankrupt Bill exempting from liability the homesteads of settlers in all the states where that exemption had been established by state law. He always advocated the reservation of public lands for actual settlers. 
At the end of the Thirty-ninth Congress, in March, 1867. Kasson was again appointed a commissioner from the United States to European governments to make further postal conventions with them, and signed them with Great Britain, Belgium, Holland, Germany, Switzerland and Italy. In 1873 in recognition of his services in metrical reform he was made a member and first chairman of the American Metrological Society, organized at Columbia College, New York.

During his absence in Europe in the fall of 1867, the people of his home county elected him to the legislature of Iowa for the purpose of securing state action for the erection of a new eapitol at Des Moines. This election was repeated in 1869 and 1871, when the Fourteenth General Assembly consummated the legislation desired. The contest which he conducted through three successive assemblies became memorable in the annals of the state, and secured still more for him the confidence and attachment of the people.

After making a long tour in Europe and parts of Africa and Asia in 1870 and 1871, Mr. Kasson was called home to take his seat for the last time in the legislature in January, 1872. In the following fall he was elected to the Forty-third Congress, by an unexpectedly large vote from the ten counties of eentral Iowa, which now composed his district; and was re-elected to the Forty-fourth Congress from the same district in 1874. During the Forty-third Congress he again served on the Ways and Means Committee, and in the Fortyfourth, which was Democratic, he was appointed on the Banking, and Currency and Pacific Railroad Committees, and was prominent in various debates. He led the movement for the repeal of the odious provision known as the "Salary Grab," which the previous eongress had passed. He opposed all further land grants to railroads, and defeated that proposed for the Texas Pacific Railroad.

During these congresses the wear and tear of congressional service, which was not confined to legislative duties alone, but embraced an immense correspondence with constituents about pension and other elaims and demands for personal and political favors, added to his annual speaking eampaign, had told upon Mr. Kasson's strength as well as his congres- 
sional ambition. He resolved to retire at the end of that congress, and so declined to be a candidate for re-nomination in the fall of 1876. In that last session of the Forty-fourth Congress oecurred the great trial before the historic Tribunal of Fifteen of the right of Rutherford B. Hayes to the presidency, contested by Mr. Tilden of New York, which excited intense and even passionate interest throughout the United States. Mr. Kasson was selected by the Republican committee in charge to make the opening argument in the ease on the part of the Republicans in congress. This speech won great praise and was telegraphed in full to the press of the nation, and was also published in a pamphlet and widely circulated. Soon after the inauguration of President Hayes he offered Mr. Kasson the post of minister plenipotentiary to Spain, and afterward the alternative of aceepting that to Austria-Hungary. The latter was accepted by him as having greater diplomatic interest owing to the Russo-Turkish War then waging near the boundaries of that empire, and the prospective conference of the Powers at Vienna. He oceupied that post for four years to the satisfaction of his own government, as well as to that of Count Andrassy, the Austro-Hungarian premier. While there the United States government gave him a commission as special envoy to the new Servian government to negotiate a commercial treaty, and he visited Belgrade for that purpose. He also paid an unofficial visit to Montenegro, where he was entertained by the prince of that interesting people.

During his absence in Europe the Republicans had lost the Iowa district which Mr. Kasson had formerly represented in Congress. Toward the close of the Hayes administration his former constituents reguested his return to become their candidate for the Forty-seventh Congress, in the hope of recovering the district to the Republicans. He returned for that purpose, made a successful eanvas, and took his seat in congress in 1881 for the fifth time from the Capital District of Iowa. In this Congress he was an unsuccessful eandidate for speaker of the House, and was appointed chairman of the committee on Reform of Civil Service, and to the second place on committee of Ways and Means and of Foreign 
Affairs. From the first committee he reported the senate bill, for reforming the eivil service, and secured its passage in the House. From the seeond he reported, and in two speeches advocated and secured the passage of the bill, providing a business commission to revise the tariff. From the third he made an elaborate report in favor of the construction of the Nicaragua Canal, with a bill in aid thereof.

$\mathrm{He}$ was again re-elected to the Forty-eighth Congress, which was Democratic, and was appointed as before on the Ways and Means Committee.

It was during this, his sixth term in Congress, that some diplomatic trouble arose between the then United States minister to Germany and the German chancellor, which resulted in chilling the relations between the two governments, and in the resignation of our minister. President Arthur, without prior consultation with him, sent the nomination of Mr. Kasson to the Senate as envoy extraordinary and minister plenipotentiary to Germany to supply the vacaney thus ereated, and restore good relations. Wishing in any event to retire from congress at the end of this term, he accepted the appointment, and served as minister at Berlin until after the first inauguration of President Cleveland, when in accordance with the American custom he tendered his resignation to the new administration. The satisfaction which he gave to Prince Bismarck and his government was attested by a request made by the German government to that of President Cleveland for the retention of Mr. Kasson as United States minister at the German capital-an unusual and distinguishing honor from that supreme chief of European diplomacy, Prince Bismarek.

It was during this service, and in the winter of 1884-85, that the "Congo Conference" of fourteen governments assembled under the presidency of Prince Bismarek. Its object was to establish the international relations of that vast newlydiscovered region ealled the Congo Free State, with a view to equality of international rights therein, to the promotion of its civilization and to the preservation of its peace. Mr. Kasson was specially aceredited thereto by the United States government as its representative. Its beneficial work has 
passed into history. In a German review of that conference Mr. Kasson was credited, next after the German representatives, with having done the most to shape its useful results. It was upon his proposition that the "Conventional Basin of the Congo" was enlarged so as to embrace about twice the territory originally included, and extending across Afriea from ocean to ocean. In this region the people of all countries were to enjoy equal commercial, educational and religious privileges, and their citizens equal protection. He also, in the interest of civilization and perpetual peace, proposed an article agreeing to the arbitration of international disputes in all cases arising in or concerning these territories, instead of a resort to war. This was aceepted by all but two of the fourteen governments; but the refusal of these two compelled the modification of that proposition after long negotiation, into a mutual engagement to resort in all cases to friendly mediation before having recourse to war, while reserving their optional resort to arbitration. It was the first general agreement recorded in history among powerful, independent and alien nationalities looking to the adjustment of all future differences by the peaceful intervention of third parties.

After his recall from Germany Mr. Kasson turned his attention to literary work, especially that of historical character. But his diplomatic experience and ability were again to be called into service. The three governments of the United States, Germany and Great Britain, had in vain attempted to settle their differences concerning the Samoan Islands in a conference at Washington, held under the first administration of President Cleveland. It was later agreed that a further conference should assemble at Berlin on the subject. In the meantime President Harrison succeeded Mr. Cleveland, and one of his earliest appointments was that of Mr. Kasson at the head of a commission, three in number, to meet the same number of delegates from each of the other governments in a conference at Berlin in 1889, to settle all the disputed points. Passing through London, Mr. Kasson had an interview on the subject with Lord Salisbury. The conference was successfully concluded at Berlin; and the 
chief point of the contention of the United States was gained, as the result of friendly private negotiations between $\mathrm{Mr}$. Kasson and Count Bismarck, Minister of Foreign Affairs.

Since his return from that mission, Mr. Kasson has led a private and tranquil life, relieved by occasional travel to the remoter lands of the North Atlantic and Aretic Seas, and to various portions of Europe and America. His life has been industrious as well as active and successful. He has made countless speeches in political campaigns in many States since 1860 and in Congress, many of which have been separately published for general eirculation. He has also delivered many lectures before associations, and the public, on various subjects. He has written for the reviews and magazines; notably two articles on the Monroe Declaration (No. Amer. Rev. Sept. and Dec., 1881) ; on Municipal Reform ( $\mathrm{Tb}$. Sept., 1883); on the Congo Convention (Ib. Feb., 1886); on Bismarek, Man and Ninister (Ib. Aug., 1886); the Hohenzollern Kaiser (Ib. April, 1888); the Western View of the - Tariff (The Forum, Dec., 1887).

In 1887, he was ehosen president of the Interstate Commission to celebrate in that year the centennial of the American Constitution, under the shadow of Independence Hall at Philadelphia. In that connection he prepared a brief history of the formation of the United States Constitution and its causes, which was published in the memorial volumes of that anniversary (pp. 133, Vol: L. Lippineott Co. Phila. 1889). In 1890 he delivered a course of ten lectures on the development and history of diplomacy before the Lowell Institute of Boston; and subsequently two eourses of lectures on the same subject before the Johns Hopkins University in Baltimore. His address before the General Assembly, state officers and people of Iowa upon the inauguration of their new State Capitol is remembered in that state as an Iowa classic, and is published among the state documents, 1884. He has had a large correspondence with men eminent in official and literary eircles, much of which is now deposited in the collections of the State Historical Department at the Capital of Iowa. 
Mr. Kasson is fond of society, whether that of royal court rircles in Europe, or the more familiar circles of a country village at home. He was for many years a member of the Society of Free Masons in the West, and is a member of the Pioneer Lawmakers' Association of Iowa; of the National Geographic and Columbia Historical Societies of Washington; and a governor of the Metropolitan and Chevy Chase Clubs of the same eity. He was honored with the degree of Doctor of Laws by the University of Vermont. He is a member of the Protestant Episeopal Church, and of the Board of Cathedral Trustees of the Diocese of Washington. Born into a Democratic family, he passed early through the Free Soil episode into the Republican party, to which he has since constantly adhered.

Mr. Kasson's "military service" is limited to one unhappy night, during his term as assistant postmaster general. Hearing of the fighting at Bull Run, he drove rapidly from Washington toward the front, meeting the rapid movements of suared, non-eombatant fugitives on the way. Pushing on against the tide till after dark, he arrived at a place called Goodwin's tavern. Here his earriage was sent back to the city; he mounted an abandoned musket to his shoulder, moved to a dark part of the road, and began a sentinel's regular pacing to and fro across the highway, ordering all the routed soldiers and teamsters to halt and form camp by the tavern, where was good water, and where an escaping commissary wagon was ordered to furnish bread. Strangely enough none disputed his orders, the camp was formed, the wearied soldiers slept. At two o'clock in the morning a regular lieutenant of the army rode up on the route of fugitives and told this volunteer sentinel that the army orders were to fall back of the defences of Washington. Mr. Kasson then roused his eamp, having but a single soldier who refused to get up, and followed his command as rear guard, rousing and encouraging them who faltered with fatigue, until they entered the fortifications of the Potomac. General Burnside on horseback, weary and mud splashed, passed him on the way. Mr. Kasson crossed the long bridge into the eity after 
his weary night march, just as the sun rose over the humiliated eapital. It was probably the only instance during the war where a civilian undertook to command armed forces and was obeyed.

The reader will observe that the foregoing fragment was written by Mr. Kasson about 1895 and his death occurred on the 18 th day of May, 1910 After the sketch was written, President McKinley, in 1899, recognizing Mr. Kasson's great ability and experience in international diplomacy, appointed him to the important position of special commissioner plenipotentiary for the negotiation of commercial treaties with other nations, and also as a member of the British-American Joint High Commission for the settlement of differences with Canada. He proceeded at once to negotiating reciprocity treaties with the leading countries of both Europe and South America. His work was more difficult than was that of Secretary Blaine in negotiating his famous reciprocity treaties, because under the then recent Dingley tariff law other countries were somewhat resenting the strong protective policy of this country. But laboring with great skill and perseverance and with an eye single to the future interests of this country in its trade with other nations, he was successful in completing several agreements of limited scope, which did not need ratification by the Senate, and which became operative by proclamation of the President, and at least twelve treaties, which had to be submitted to the Senate before they became operative. This was the largest number of commercial treaties ever before negotiated by one officer on the part of the United States. Mr. Kasson's great disappointment as a diplomat was the refusal of the Senate of the United States to ratify these treaties. The unique distinction paid him by the President, which should have been the crowning glory of his long and suceessful career in diplomacy, turned out to be his great disappointment. Although the press largely commended his work and the President desired him to remain longer in the position, he resigned in 1903, and the position lapsed. This was his last official work. The remaining seven years of his life was spent mostly in quiet retirement at his home in Washington, where he died May 18, 1910. Thus ended the life of this accomplished orator, lawyer, legislator, statesman and diplomat.

The series of presidential commissions, diplomas and other tokens of honor and attainment of Mr. Kasson, deposited in the Historical Department, excel in number and excel in character all similar collection extant in Iowa.-Editor.

\section{SAD AFFAIR.}

The saddest incident connected with the battle at this place was the killing of Miss Magy Virginia Wade by the rebel sharp-shooters posted in the outskirts of the town. She was attending a sick sister at the time, and the house standing in an exposed position, she was in constant danger. A minie ball from one of their rifles struck her in the head and killed her instantly. Miss Wade was aged 20 years 1 month and 7 days, and was a young lady of good character and much respected. This is only one of the many painful incidents connected with this eruel war.-Gettysburg, Pa.-Star and Banner, July 9, 1863. (In the newspaper collection of the Historical Department of Iowa.) 
Copyright of Annals of Iowa is the property of State of Iowa, by \& through the State Historical Society of Iowa and its content may not be copied or emailed to multiple sites or posted to a listserv without the copyright holder's express written permission. However, users may print, download, or email articles for individual use. 